\title{
Integrated approach to diagnosis of associated occupational asthma and rhinitis
}

\author{
Sébastien Nguyen MD CM${ }^{1,2}$, Roberto Castano MD PhD ${ }^{1,2}$, Manon Labrecque MD MSc ${ }^{1,2}$
}

\author{
S Nguyen, R Castano, M Labrecque. Integrated approach to \\ diagnosis of associated occupational asthma and rhinitis. Can \\ Respir J 2012;19(6):385-387.
}

Patients with coexisting work-related rhinitis and asthma would benefit from an adequate and simultaneous recognition of both diseases. The present case illustrates the advantages and importance of using an integrated approach to confirm a diagnosis of occupational rhinitis (OR) and occupational asthma (OA).

A 38-year-old woman, who worked as an animal laboratory technician since 2004, first noticed the appearance of rhinitis and conjunctivitis symptoms in 2007 when she was exposed to rats. A skin-prick test with rat extract was strongly positive. A specific inhalation challenge with parallel assessment of nasal and bronchial responses was conducted. After $10 \mathrm{~min}$ of exposure, she developed rhinitis and conjunctivitis symptoms, her forced expiratory volume in $1 \mathrm{~s}$ dropped by $27.5 \%$ and her nasal volume, measured by acoustic rhinometry, decreased by $80 \%$ from baseline values. After allergen exposure, induced sputum and nasal lavage examination demonstrated an increase in eosinophils (11\% and 20\%, respectively). A diagnosis of associated allergic $\mathrm{OA}$ and $\mathrm{OR}$ was confirmed and she was advised to stop working with rats.

A systematic and parallel diagnostic approach enables confirmation of a diagnosis of $\mathrm{OA}$ and $\mathrm{OR}$ in patients complaining of work-related rhinitis and asthma symptoms.

Key Words: Occupational asthma; Occupational rhinitis; Specific inhalation challenge; United airway disease

Learning objectives

- To raise awareness of the potential coexistence of asthma and rhinitis at the workplace.

- To illustrate the importance and feasibility of an integrated diagnostic approach to occupational asthma (OA) and occupational rhinitis (OR).

CanMEDS competency: Medical expert

Pre-test

- What are the steps involved in the investigation of a suspected case of concurrent OA and OR?

\section{CASE PRESENTATION}

A 38-year-old woman, who worked as an animal laboratory technician since 2004, was referred for suspected OA. In 2007, she first noticed rhinitis and conjunctivitis symptoms when she manipulated rat litters. Nasal symptoms improved on weekends and at night. Six months later, rhinitis symptoms were accompanied by cough and chest tightness whenever she was exposed to rat litter. A chest examination was unremarkable. A rhinoscopic examination revealed pale nasal mucosa, edema of the interior and middle turbinates, and thin, clear nasal secretions. A skin-prick test was positive for commercial extracts of rat epithelia (Omega, Canada) (wheal $10 \mathrm{~mm} \times 5 \mathrm{~mm}$ ) and grass pollen. Total serum immunoglobulin (Ig) E levels were elevated (139 kU/L).

\section{Une approche intégrée du diagnostic d'association d'asthme et de rhinite professionnels}

Les patients ayant une association de rhinite et d'asthme professionnels profiteraient d'un diagnostic pertinent et simultané des deux maladies. Le présent cas illustre les avantages et l'importance d'utiliser une approche intégrée pour confirmer un diagnostic de rhinite professionnelle (RP) et d'asthme professionnel (AP).

Une femme de 38 ans, qui travaillait comme technicienne de laboratoire pour animaux depuis 2004, a d'abord remarqué l'apparition de symptômes de rhinite et de conjonctivite en 2007, lorsqu'elle a été exposée à des rats. Une intradermoréaction à un extrait de rat s'est révélée fortement positive. Elle a subi un test de provocation nasale avec évaluation parallèle des réponses nasales et bronchiques. Au bout de 10 minutes d'exposition, elle s'est mise à présenter des symptômes de rhinite et de conjonctivite, son volume expiratoire maximal par seconde a chuté de $27,5 \%$ et son volume nasal, mesuré par rhinométrie acoustique, a diminué de $80 \%$ par rapport aux valeurs de départ. Après l'exposition aux allergènes, l'expectoration induite et l'examen par lavage nasal ont démontré une augmentation des éosinophiles (11\% et $20 \%$, respectivement). Les intervenants ont confirmé un diagnostic d'association d'AP et de RP et lui ont conseillé d'arrêter de travailler avec des rats.

Une approche diagnostique systématique et parallèle permet de confirmer un diagnostic d'AP et de RP chez des patients qui se plaignent de symptômes de rhinite et d'asthme liés au travail.

${ }^{1}$ Respiratory Research Division, Research Center, Hôpital du Sacré-Coeur de Montréal; ${ }^{2}$ Faculty of Medicine, Université de Montréal, Montreal, Quebec

Correspondence: Dr Sébastien Nguyen, Respiratory Research Division, Research Center, Hôpital du Sacré-Coeur de Montréal, 5400 Boulevard Gouin Ouest, Montréal, Québec H4J 1C5. Telephone 514-338-2222, e-mail sebastien.nguyen@mail.mcgill.ca 


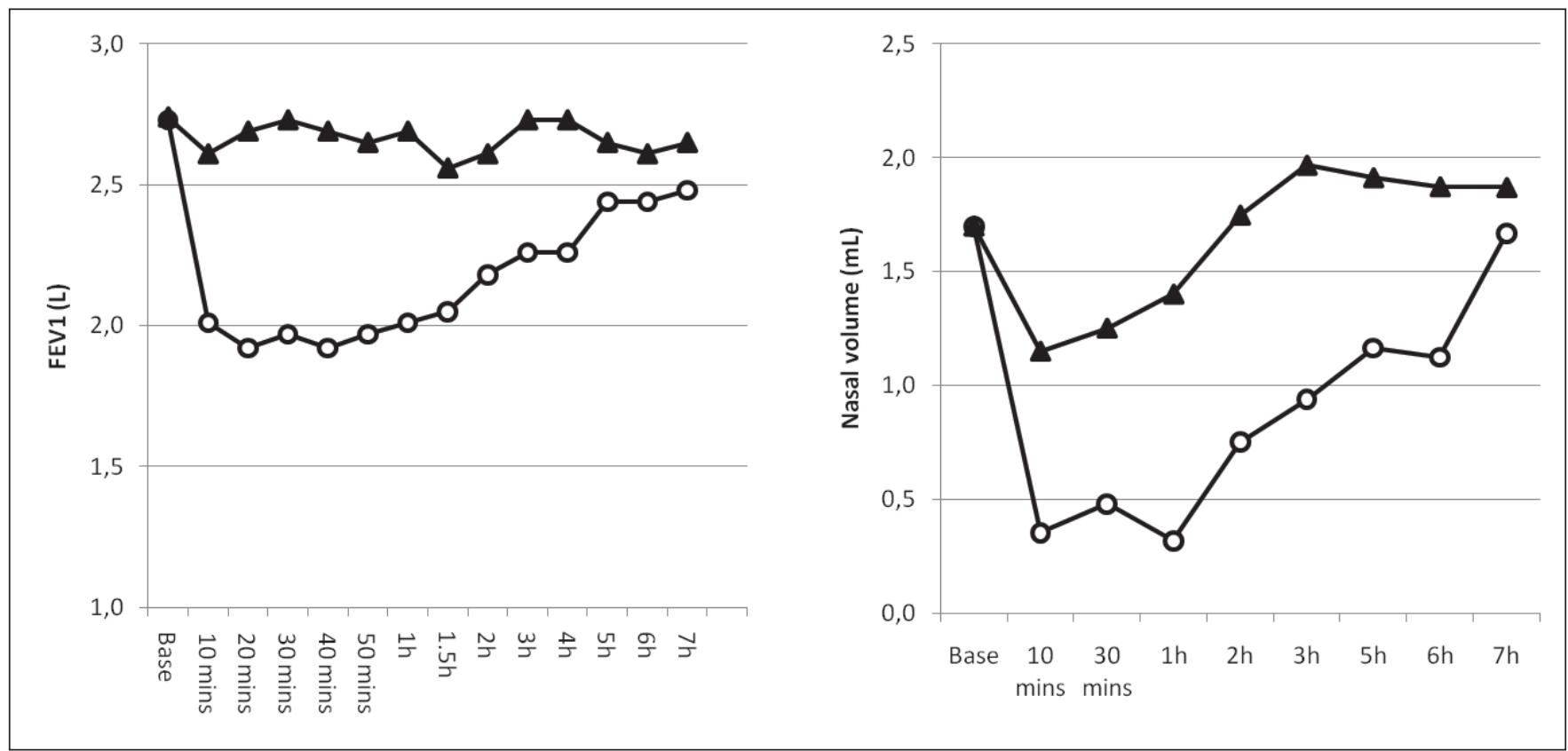

Figure 1) Changes in forced expiratory volume in $1 \mathrm{~s}\left(\mathrm{FEV}_{1}\right)$ (left panel) and total nasal volume (right panel) after control and allergen challenge. Provocation day (circle) and control day (triangle)

(NAL) to assess changes in inflammatory cells (3). On the control day, there was no significant change in $\mathrm{FEV}_{1}$ or nasal volume after exposure to lactose, which was used as the control agent. At the end of the control day, IS and NAL eosinophils were $4.0 \%$ and $3.4 \%$, respectively. The following day, after exposure to rat allergens, she developed rhinitis and conjunctivitis symptoms and her $\mathrm{FEV}_{1}$ dropped by $27.5 \%$ and her nasal volume by $80 \%$ from baseline after $10 \mathrm{~min}$ of exposure (Figure 1). After exposure, IS and NAL examination at $6 \mathrm{~h}$ and $30 \mathrm{~min}$, respectively, demonstrated an increase in eosinophil counts (11\% and $20 \%$, respectively) compared with baseline (NAL) and to values on the control day (IS). A diagnosis of associated OA and OR was made, and she was advised to stop working with rats and to continue treatment for her rhinitis and asthma symptoms.

\section{DISCUSSION}

During the past few years, the global pathogenic view of respiratory allergy has changed. Asthma and rhinitis often coexist, suggesting the concept of a 'united airway disease' (4). Occupational respiratory diseases represent an interesting model to study the relationship between rhinitis and asthma. Indeed, evidence is increasing showing the frequent coexistence of both diseases at the workplace $(5,6)$. The definition of OA is widely accepted and defined as:

...a disease characterized by variable airflow limitation and/or hyperresponsiveness and/or inflammation due to causes and conditions attributable to a particular occupational environment and not to stimuli encountered outside the workplace.

A recent definition of OR modelled in that of OA has been proposed:

$\mathrm{OR}$ is an inflammatory disease of the nose which is characterized by intermittent or persistent symptoms (i.e. nasal congestion, sneezing, rhinorrea, itching), and/or variable nasal airflow limitation and/or hypersecretion due to causes and conditions attributable to a particular work environment and not to stimuli encountered outside the workplace (7).

Moreover, guidelines for the diagnosis of this condition using objective means have been proposed (7). The key issue in the above definitions is the objective demonstration of changes in functional lung and nasal parameters. In the context of work-related symptoms, a diagnosis of both $\mathrm{OR}$ and $\mathrm{OA}$ have medicolegal consequences, making a comprehensive investigation using objective diagnostic tools imperative.

The present case illustrates the diagnostic approach followed at our institution to assess a suspected case of associated $O R$ and $O A$ due to laboratory animal allergens, which is a frequent cause of workrelated rhinitis and asthma (8). The investigation of $O R$ and $O A$ includes both assessing the presence of rhinitis and asthma, and demonstrating their work-relatedness. A detailed medical and occupational history is the first step in the investigation; however, the clinical history has a low specificity to establish a diagnosis, which should be confirmed by objective tests $(9,10)$. Once the diagnosis of $\mathrm{OA}$ and/or OR is suspected by the clinical history, it can be confirmed by performing SIC. This test is considered to be the 'gold standard' for confirming OA. In contrast, there is no standardized procedure to confirm OR; however, assessment of changes in clinical and functional parameters by means of objective and subjective methods during nasal provocation testing represents the current recommended approach for confirming OR (7). In summary, the present case illustrates the feasibility of an integrated diagnostic approach for patients complaining of work-related respiratory symptoms suggestive of $\mathrm{OR}$ and OA. Such an approach is feasible, convenient and, therefore, recommended because there are known implications for therapy. In fact, it has been shown that treatment of allergic rhinitis with intranasal corticosteroids has the capacity to modulate different aspects of the inflammatory cascade, which may lead to improvement in asthma symptoms and lung functional parameters (11). Ultimately, the results of an optimal 'united' diagnosis and management of rhinitis and asthma could translate into better outcomes in addtion to fair compensation for patients with OA and OR.

\section{Post-test}

- A detailed medical and occupational history and physical examination is the first step in the investigation. This should be followed by immunological tests to assess sensitization to common inhalants and specific occupational allergens. The diagnosis of $\mathrm{OA}$ and $\mathrm{OR}$ is confirmed by specific inhalation challenge with objective monitoring of lung and nasal functional and inflammatory parameters. 


\section{REFERENCES}

1. Vandenplas O, Malo JL. Inhalation challenges with agents causing occupational asthma. Eur Respir J 1997;10:2612-29.

2. Clement PA, Gordts F. Consensus report on acoustic rhinometry and rhinomanometry. Rhinology 2005;43:169-79.

3. Castano R, Gautrin D, Theriault G, Trudeau C, Ghezzo H, Malo JL. Occupational rhinitis in workers investigated for occupational asthma. Thorax 2009;64:50-4.

4. Bousquet J, Khaltaev N, Cruz AA, et al. Allergic Rhinitis and its Impact on Asthma (ARIA) 2008 update (in collaboration with the World Health Organization, GA[2]LEN and AllerGen). Allergy 2008;63(Suppl 86):8-160.

5. Bousquet J, Vignola AM, Demoly P. Links between rhinitis and asthma. Allergy 2003;58:691-706.

6. Malo JL, Lemiere C, Desjardins A, Cartier A. Prevalence and intensity of rhinoconjunctivitis in subjects with occupational asthma. Eur Respir J 1997;10:1513-5.
7. Moscato G, Vandenplas O, Gerth Van Wijk R, et al. Occupational rhinitis. Allergy 2008;63:969-80.

8. Krakowiak A, Szulc B, Gorski P. Occupational respiratory diseases in laboratory animal workers: Initial results. Int J Occup Med Environ Health 1997;10:31-6.

9. Moscato G, Vandenplas O, Van Wijk RG, et al. EAACI position paper on occupational rhinitis. Respir Res 2009;10:16.

10. Leonard Bernstein MC-Y, Malo J-L, Bernstein DI, eds. Asthma in the Workplace, 3rd edn. New York: Taylor \& Francis; 2006.

11. Taramarcaz P, Gibson PG. Intranasal corticosteroids for asthma control in people with coexisting asthma and rhinitis. Cochrane Database Syst Rev 2003;(4):CD003570. 


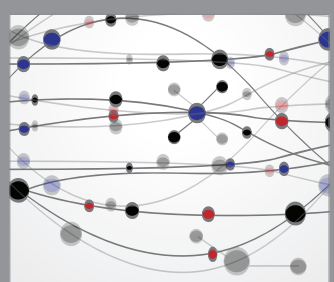

The Scientific World Journal
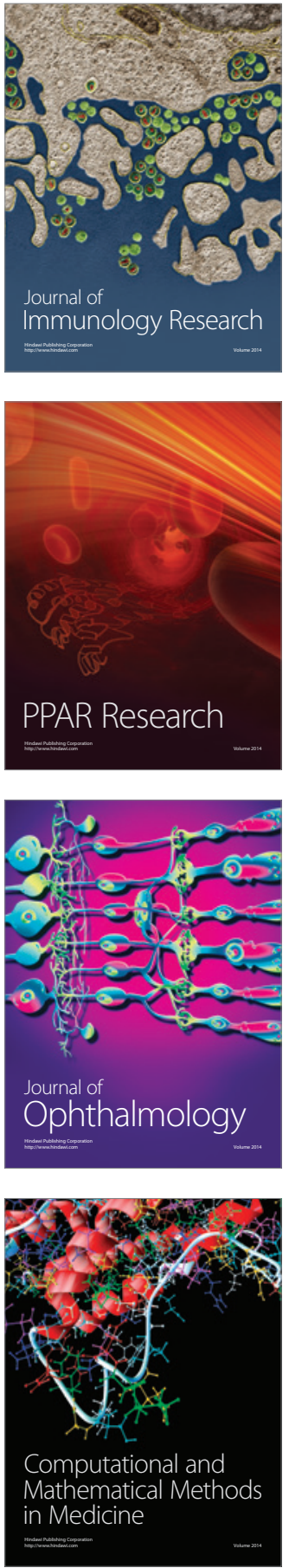

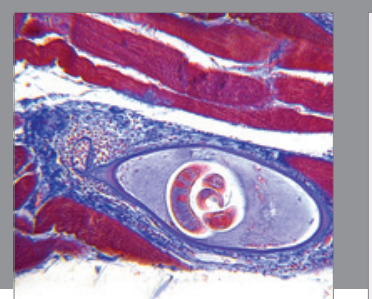

Gastroenterology Research and Practice

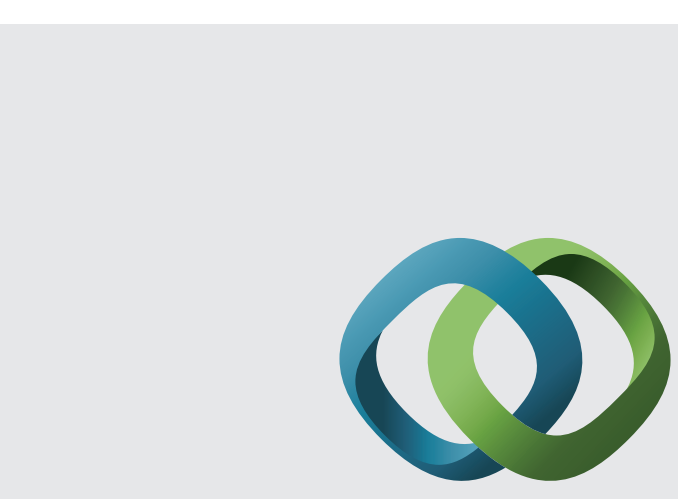

\section{Hindawi}

Submit your manuscripts at

http://www.hindawi.com
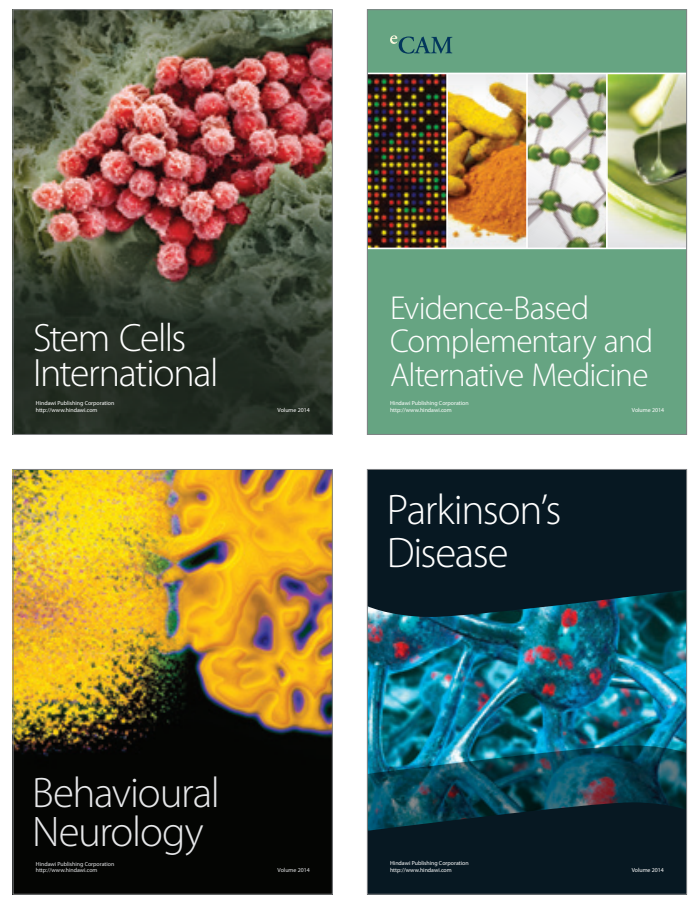
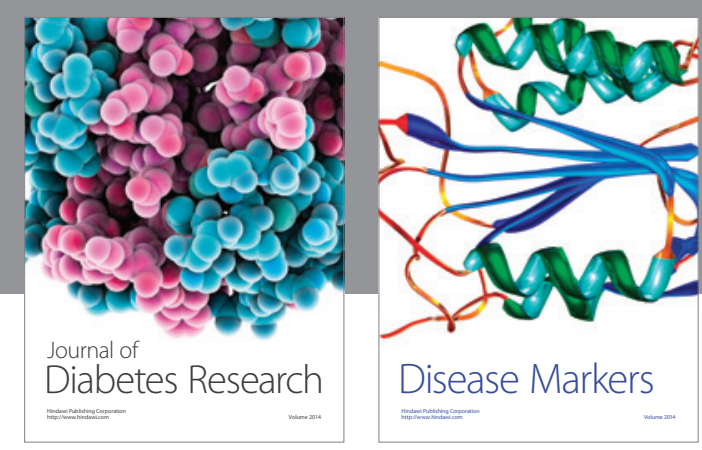

Disease Markers
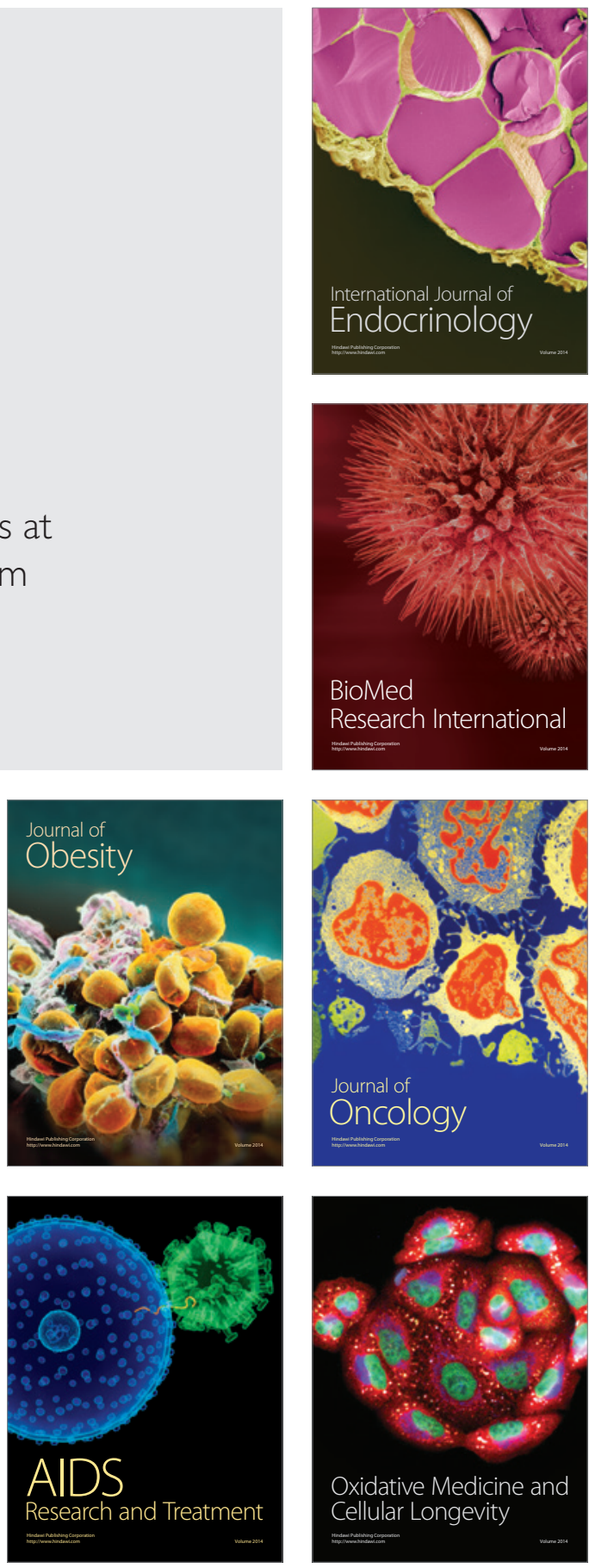